\title{
How to increase the value of urban areas for butterfly conservation? A lesson from Prague nature reserves and parks
}

\author{
MARTIN KONVICKA ${ }^{1,2}$ and TOMAS KADLEC ${ }^{2,3,4}$ \\ ${ }^{1}$ Faculty of Science, University of South Bohemia, Branisovska 31, 37005 Ceske Budejovice, Czech Republic; \\ e-mail: konva333@gmail.com \\ ${ }^{2}$ Institute of Entomology, Czech Academy of Sciences, Branisovska 31, 37005 Ceske Budejovice, Czech Republic \\ ${ }^{3}$ Faculty of Sciences, Charles University, Vinicna 7, 12844 Prague, Czech Republic \\ ${ }^{4}$ Faculty of Environmental Sciences, Czech University of Life Sciences, Kamycka 129, 16521 Prague, Czech Republic
}

Key words. Insect conservation, habitat fragments, Lepidoptera, reserves, urbanisation, Zygaenidae

\begin{abstract}
Cities contain only a low representation of natural and semi-natural habitats, existing in fragments surrounded by built-up areas. In 2003-2004, we surveyed butterflies and Zygaenidae moths in 21 reserves and 4 parks within the city of Prague, Czech Republic, situated from the periphery to city centre. A total of 85 species ( $47 \%$ of the Czech fauna of the study groups) was detected, 22 of them being of conservation concern. Ordination analyses of the local assemblages revealed that the richest sites were large, situated far from the city centre, on alkaline bedrocks, south- to southwest oriented, and hosting high numbers of vegetation types and vascular plant species. We then used generalised linear models to fit responses of individual species to the main ordination gradient, corresponding to increasing urbanisation. Out of 60 species that met criteria for the modelling, none responded positively to urbanisation. Twenty displayed negative linear response; these urban avoiders contained a surplus of mesophilous species presumably preferring rural landscapes. Further 29 species (suburban adaptable) responded in domed manners, peaking at the city periphery. Prevailing among them were xerophilous specialists inhabiting large grassland reserves at the Prague outskirts. Finally, eleven urban tolerant species did not respond to urbanisation at all, containing three highly mobile species, three xerothermophilous specialists, and five species utilising shrubs or trees and finding suitable conditions even in urban parks. Suburban adaptable butterflies apparently benefit from such suburban environments as gardens, road or railway verges, collectively increasing the connectivity of remnants of seminatural habitats. The fact that arboreal species persist even in urban parks, whereas common grassland species are absent there, implies that the quality of urban habitats might be increased by a more sensitive management of urban green spaces, such as leaving aside small temporary fallows or adapting lawns mowing schemes.
\end{abstract}

\section{INTRODUCTION}

Worldwide loss of natural habitats, intensification of land use and urbanisation are prompting ecologists and conservation biologists to focus on human-altered biotopes, including urban areas (Angold et al., 2006). Reserves and other natural islets within metropolitan areas offer nature experience to an increasing proportion of the human population (Miller \& Hobbs, 2002; Shochat et al., 2006) while adding to the total area of conserved land. The latter may be of particular importance, because urban locations tend to be naturally species rich (Kühn et al., 2004); some urban biotopes, such as road verges or brownfields, may function as surrogates for biotopes already lost from intensively managed lands (Harrison \& Davies, 2002; Eyre et al., 2004; Gutierrez, 2005; Valtonen et al., 2007; Lundholm \& Richardson, 2010); and some range-restricted species have become trapped within large metropolitan areas, so that preserving their urban populations is the only available option for their in situ conservation (Mattoni et al., 2001).

Responses of butterflies to urbanisation have been investigated in various regions of the world and using a variety of methods, such as analysing distribution maps (Hardy \& Dennis, 1999), walking transects from city cen- tres to periphery (Kitahara \& Fujii, 1994; Blair, 1999; Hogsden \& Hutchinson, 2004), comparing assemblages differently affected by urbanisation (Koh \& Sodhi, 2004; Collier et al., 2006; Ockinger et al., 2009) and working with molecular markers (Takami et al., 2004; Snep et al., 2006). The studies agree that densities of specialised species decrease from peripheries towards city centres. Blair \& Launer (1997) distinguished three broad groups of city-dwelling butterflies (see also McIntyre, 2000). Urban exploiters reach higher densities in cities than elsewhere; in the case of butterflies, they may depend on ornamental plants (cf. Shapiro, 2002). Suburban-adaptable species are not directly harmed by urban environments, but their population densities are not higher in cities than in rural landscapes. In contrast, urban avoiders decline in numbers with urbanisation; their populations in cities represent remnants of former distribution in natural or rural landscapes, entrapped by urban growth. Although all urban wildlife is valuable for public enjoyment of biodiversity (Gaston et al., 2005), conservation should focus on supporting populations of suburban-adaptable and urban avoider species, which are more likely declining or threatened (Kitahara \& Fujii, 1994; Jarosik et al., 2011).

To conserve urban butterfly populations efficiently, two prerequisites should be met. The first is a good knowl- 
edge of the distribution of individual species. This inherently local knowledge will always rely on species distribution recording (e.g., Dennis \& Hardy, 2001; Höttinger, 2002). A more general issue concerns an understanding of how species respond to urbanisation. Here, local studies from individual cities may disclose general patterns, transferable among geographic regions.

We address the latter question for urban Prague, Czech Republic. We compared local butterfly assemblages recorded in 25 urban reserves and parks, situated at various distances from the city centre and variously affected by their urban surroundings. We use ordination analyses to answer the following questions: (1) Which external predictors characterising the reserves form the dominant gradient influencing the composition of local assemblages? (2) By grouping Prague butterflies according to their response to urbanisation, can categories distinguished by Blair \& Launer (1997) be recognised? (3) If so, on which habitats do members of the three groups depend, and what conservation approaches could contribute to their persistence in the urban area.

\section{MATERIAL AND METHODS}

\section{Study system}

Owing to a rugged terrain, diverse bedrock and location in a warm Vltava River valley, Prague hosts a remarkable biodiversity, protected in 88 reserves of a total area of 2350 ha (Nemec $\&$ Lozek, 1997). They comprise a broad array of habitats from wetlands and remnants of ancient woods to xeric grasslands on steep rocky slopes. They are replaced by larger parks towards the city centre, collectively forming a "green" urban network. In a previous study, we analysed changes of butterfly assemblages, based on presence-absence records, in 25 sites containing xeric grasslands, over 30 years (Kadlec et al., 2008). We detected surprisingly few losses, but found statistically detectable changes in species composition. Xerophilous species requiring shortsward grasslands decreased, while species exploiting taller xeric or mesic vegetation increased.

This study analyses the present records only, but does so in more detail. Whereas Kadlec et al. (2008) relied on presenceabsence data, as abundances were not recorded 30 years ago, abundance data are available for the present situation. The sites comprise 21 reserves and four parks (Table 1), selected so that (i) they cover a balanced representation of small and large, isolated and clustered, and central and peripheral sites; (ii) if reserves, they contained xeric grasslands at the time of their establishment.

\section{Butterfly survey}

Butterflies (Papilionoidea and Hesperioidea) and burnets (Zygaenidae) are together referred to as "butterflies"; the nomenclature follows Lastuvka (1998). The surveys were carried out in 2003 and 2004. Each site was visited monthly from May to August, summing to eight visits per reserve. The visits were limited to 10:00-16:00 (CEST) and to suitable weather $\left(>17^{\circ} \mathrm{C}\right.$, sunny, none to mild wind). During each visit, we searched the entire reserve, covering all biotopes present and trying to locate as many species as possible. Approximately the same route was followed each time, varying in details in order to check places with seasonal concentrations of butterflies, e.g., nectar-rich patches. Visit duration, in person-hours, scaled with site area $(<1$ ha: $0.5 \mathrm{~h},<10$ ha: $1 \mathrm{~h},<100$ ha: $1.5 \mathrm{~h}$, above 100 ha: $3 \mathrm{~h}$ ). The sequence of the visits was randomised within
TABLE 1. List of surveyed reserves and parks $(*)$, with their areas, durations of butterfly recording visits, and distance from city centre. Karlovo namesti, a park at one of the central Prague squares, was considered as having zero distance.

\begin{tabular}{lccc}
\hline Site & Area (ha) & $\begin{array}{c}\text { Visit dura- } \\
\text { tion (min) }\end{array}$ & $\begin{array}{c}\text { Urban dis- } \\
\text { tance }(\mathrm{km})\end{array}$ \\
\hline Baba & 7.3 & 60 & 5.18 \\
Barrandovske skaly & 11.6 & 90 & 5.23 \\
Bohnicke udoli & 4.6 & 60 & 6.79 \\
Branicke skaly & 9.1 & 60 & 3.75 \\
Cimicke udoli & 11.2 & 90 & 7.49 \\
Dalejsky profil & 22.8 & 90 & 8.05 \\
Divoka Sarka & 25.4 & 90 & 7.43 \\
Dolni Sarka & 6.2 & 60 & 5.65 \\
Havranka & 4.2 & 60 & 5.11 \\
Jablonka & 1.3 & 60 & 4.78 \\
Jeneralka & 1.5 & 60 & 6.02 \\
Karlovo namesti* & 4 & 60 & 0.00 \\
Lochkovsky profil & 39.1 & 90 & 10.37 \\
Nad mlynem & 4.0 & 60 & 5.52 \\
Okrouhlik & 0.6 & 30 & 6.10 \\
Petrin* & 30.0 & 90 & 1.38 \\
Podbabske skaly & 0.8 & 30 & 5.76 \\
Prokopske udoli & 101.5 & 180 & 4.78 \\
Radotinske udoli & 103.3 & 180 & 11.33 \\
Santoska - Pavi vrch* & 20.0 & 90 & 1.85 \\
Tiche udoli - Roztocky haj & 114.2 & 180 & 8.53 \\
Trojska & 1.3 & 60 & 5.23 \\
Zidovske pece* & 6.2 & 60 & 4.49 \\
Zlatnice & 3.3 & 60 & 5.19 \\
Zmrzlik & 16.4 & 90 & 10.25 \\
\hline
\end{tabular}

moths. Each species was recorded when first spotted. After the termination of a visit, all species were assigned semiquantitative abundance on the scale 1: one individual; 2 : two individuals; 3 : $<5 ; 4:<10 ; 5:<20 ; 6:<50 ; 7:<100$; and 8 : hundreds of individuals. For species not identifiable in field (Colias hyalealfacariensis, Leptidea sinapis-reali, Plebeius idas-argyrognomon, Zygaena minos-purpuralis, Adscita spp., Jordanita spp.), up to five individuals per site/visit were taken to the laboratory for genital preparation, and proportions of individual species in thus obtained samples were subsequently assigned to the numbers actually observed in the field.

\section{External variables}

Based on existing studies of determinants of the composition of butterfly assemblages in temperate grassland reserves (e.g., Wenzel et al., 2006; Kadlec et al., 2008; Knapp et al., 2008; Jarosik et al., 2011), we characterised each reserve by a set of environmental predictors:

(i) Area $(0.5-225.5 \mathrm{ha})$;

(ii) prevailing Inclination; coded by five ordinal levels: north to north-east; plain; south-east and west; south and south-west; valley with all inclinations present;

(iii) Altitude range $(15-110 \mathrm{~m})$;

(iv) Substrate; coded by three ordinal levels: nonalkaline, alkaline, combined;

(v) Bare rock presence (categories present or absent);

(vi) (vascular) Plant species numbers (117-696), taken from Sprynar \& Marek (2001);

(vii) Vegetation types, defined as the number of plant communities per site (Sprynar \& Marek, 2001) (1-25);

(viii) Urban cover - proportion of built-up cover within 100 $\mathrm{m}$ wide band around the sites $(0.01-1.00)$; 
(ix) Urban distance: the distance from city centre (Karlovo namesti) to the centroid of each reserve (0-2150 m).

\section{Analyses}

We used an indirect ordination, (partial) detrended correspondence analysis (DCA), computed in CANOCO v. 4.5 (Ter Braak $\&$ Smilauer, 1998) to visualise major gradients in butterfly distribution. Species were entered as summed abundance values from all eight visits, using the upper boundary of the semiquantitative intervals and setting the highest possible abundance to 500. Detrending by segments and log-transformation were used for computation.

A constrained linear ordination method, redundancy analysis (RDA), was used to study the effects of reserve characteristics on species composition. The method ordinates samples (= sites) according to their species composition, subject to external environmental variables. The Monte-Carlo tests (999 permutations) for the significance of relationships to environmental variables considered the temporal structure of data. The eight successive visits per site were permuted as time series, the 25 sites (within visit) were permuted in random.

We first checked for an individual effect of each external variable on the species composition of the samples. We ran two separate RDA analyses for each variable, one without and one with control for spatial position of the sites (Legendre, 1993). For the latter, we first defined a minimum adequate model describing the geographic position of the reserves by defining a model with latitude (lat), longitude (long), their second-degree polynomials, and all possible combinations (e.g., lat + long, lat · lat + long $^{2} \ldots$ ) (Titeux et al., 2004), and then simplified this model using the CANOCO forward selection procedure. The selected covariate model, y lat + long + lat · long, was used in all spatially controlled analyses.

We then constructed the following more complex RDA models: model containing all variables that were nominally significant in the separate analyses; model with all variables that remained significant after considering the spatial positions of the reserves; and two models obtained by forward selection of predictors, one not controlled and one controlled for the spatial positions.

To further study responses of individual species, we modelled species responses to the first ordination axis of the (partial) RDA containing all significant variables and controlled for spatial covariates, using the GLM-module in CanoDraw v. 4.0 (C) Petr Smilauer 1999-2002). For each species, linear and quadratic responses were modelled, assuming a Poissons' distribution of errors and log link. We then used $F$-tests to distinguish species exhibiting a response to the gradient from those not exhibiting any response, and the Akaike information criterion ( $A I C$; it seeks a balance between model complexity and fit) to decide whether linear or polynomial responses fitted the data better. To avoid biases due to inclusion of species recorded in too low numbers of individuals and/or sites, we excluded butterflies meeting any of the following criteria: total number of records $<5$; recorded in $<3$ sites; if displaying significant fit, the better-fitting GLM explained $<5.0 \%$ of variation in the data.

Finally, we compared the groups with negative, positive and nonexistent responses to the ordination in terms of representation of species endangered in the Czech Republic (Vrabec et al., 2005) and species belonging to three broadly defined biotope association categories, xerothermophilous, mesophilous and ubiquistic, taken from Benes et al. (2002).
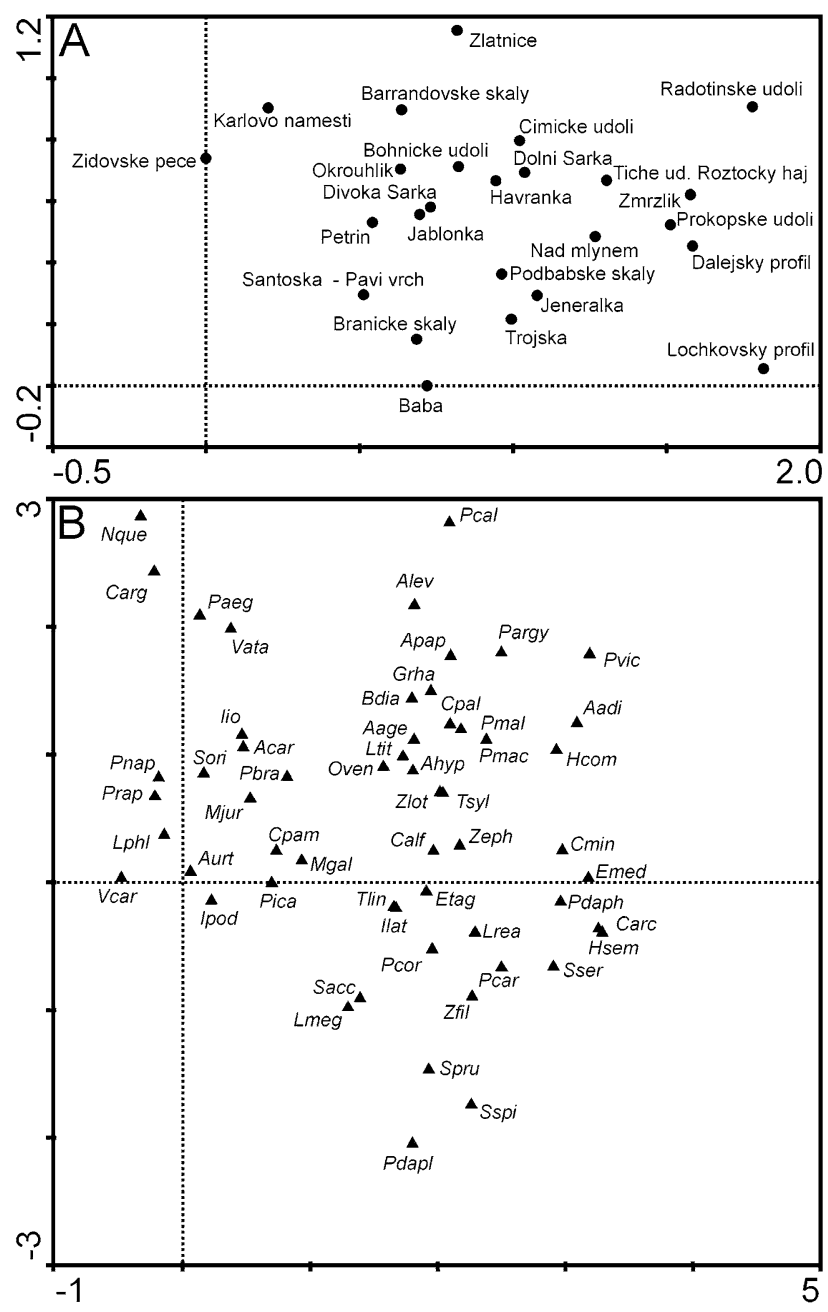

Fig. 1. Results of indirect ordination (DCA) arranging 25 Prague reserves and parks, according to the species composition of butterflies recorded in the years 2003-2004 (gradient length $=1.82 ; 1$ st axis eigenvalue $=0.20$, or $22.0 \%$ of species data variation; 2nd axis gradient $0.06,7.1 \%$ of species data variation). A - sites; B - butterfly species. See Table 1 for site details. Species abbreviations: Aadi-Argynnis adippe; AlevAraschnia levana; Acar - Anthocharis cardamines; Aage Aricia agestis; Ahyp - Aphantopus hyperanthus Apap Argynnis paphia; Aurt - Aglais urticae; Bdia - Boloria dia; Calf - Colias alfacariensis; Carc - Coenonympha arcania; Carg - Celastrina argiolus; Cmin - Cupido minimus; Cpal Carterocephalus palaemon; Cpam - Coenonympha pamphilus; Emed-Erebia medusa; Etag - Erynnis tages; Grha - Gonepteryx rhamni; Hsem - Hipparchia semele; Iio - Inachis io; Ilat - Issoria lathonia; Lmeg - Lasiommata megera; Ipod - Iphiclides podalirius; Lphl-Lycaena phlaeas;Ltit - L. tityrus; Lrea - Leptidea reali; Mjur - Maniola jurtina; Mgal - Melanargia galathea; Nque - Neozephyrus quercus; Oven - Ochlodes venatus; Paeg - Pararge aegeria; Pargy - Plebeius argyrognomon; Pbra - Pieris brassicae; Pcal - Polygonia c-album; Pcar Pyrgus carthami; Pcor - Polyommatus coridon; Pdaph $-P$. daphnis; Pdapl-Pontia daplidice; Pica-Polyommatus icarus; Pmal - Pyrgus malvae; Pnap - Pieris napi; Prap - P. rapae; Sacc - Satyrium accaciae; Sori - Scolitantides orion; Spru Satyrium pruni; Sser - Spialia sertorius; Sspi - Satyrium spini; Pvic - Pseudophilotes vicrama; Tlin - Thymelicus lineola; Tsyl - T. sylvestris; Vata - Vanessa atlanta; Vcar-Vanessa cardui; Zeph-Zygaena ephialtes; Zfil-Z. filipendulae; Zlot-Z. loti. 


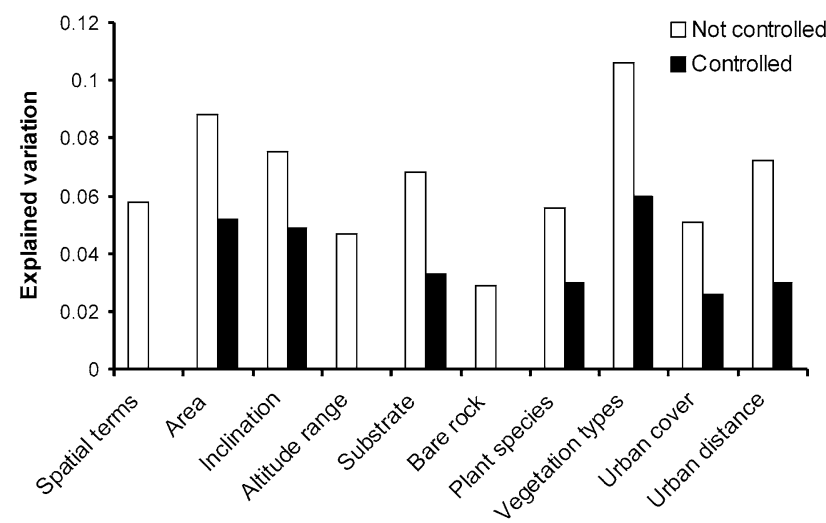

Fig. 2. Variation in the composition of butterfly assemblages, as explained by RDA analyses assessing individual effects of single predictors. The models controlled for spatial position contained covariate terms lat + long + lat $:$ long.

\section{RESULTS}

\section{Gradients structuring butterfly assemblages}

We recorded 85 species (Appendix), or 47 per cent of the species richness of butterflies and burnets occurring in the Czech Republic (mean per reserve: $35.8 \pm 14.21 \mathrm{SD}$, median: 33, range: 13-67). Twenty-two of them are threatened in the Czech Republic (mean: 5.7 \pm 4.48 SD, median: 4, range: 1-17). The proportional representation of threatened species per reserve closely correlated with total richness $\left(r_{s}=0.91, t_{(23)}=10.3, P<0.0001\right)$. Three richest sites (Prokopske udoli, Dalejsky profil, Radotinske udoli) protect deep calcareous valleys with rich arrays of biotopes ranging from rocks through grasslands to woodland. The poorest sites were parks near the city centre (Karlovo namesti, Zidovske pece) or small reserves with high proportions of forest cover (Barandovske skaly, Okrouhlik).

The main gradient in DCA separated large suburban reserves from parks in the city centre. Widely distributed ubiquitous species (large nymphalids, Pieris whites) were associated with the city centre, whereas both grassland (Pseudophilotes vicrama, Polyommatus daphnis) and open woodland (Argynnis adippe, Erebia medusa) specialists were associated with peripheral reserves. The second axis separated reserves containing solely grasslands (Baba, Jeneralka) from reserves containing some forest (Radotinske udoli, Okrouhlik) (Fig. 1A), distinguishing species of non-wooded, or even barren habitats (Pontia daplidice, Lasiommata megera) from woodland species (Pararge aegeria, Polygonia c-album) (Fig. 1B).

Inclusion of the spatial terms (lat + long + lat $\cdot$ long) caused a decrease of explained variation at the first ordination axis $(0.09,15.8 \%)$, while retaining the centreperiphery gradient. In contrast, the variation attributable to the second axis increased $(0.07,11.7 \%)$. The axis now, instead of differentiating between grassland and woodland, appears to differentiate between xeric (associated species, e.g. Zygaena laeta, Leptidea sinapis) and mesic (Leptidea reali, Lycaena tityrus) grasslands, whereas woodland butterflies ended up scattered throughout the ordination space.
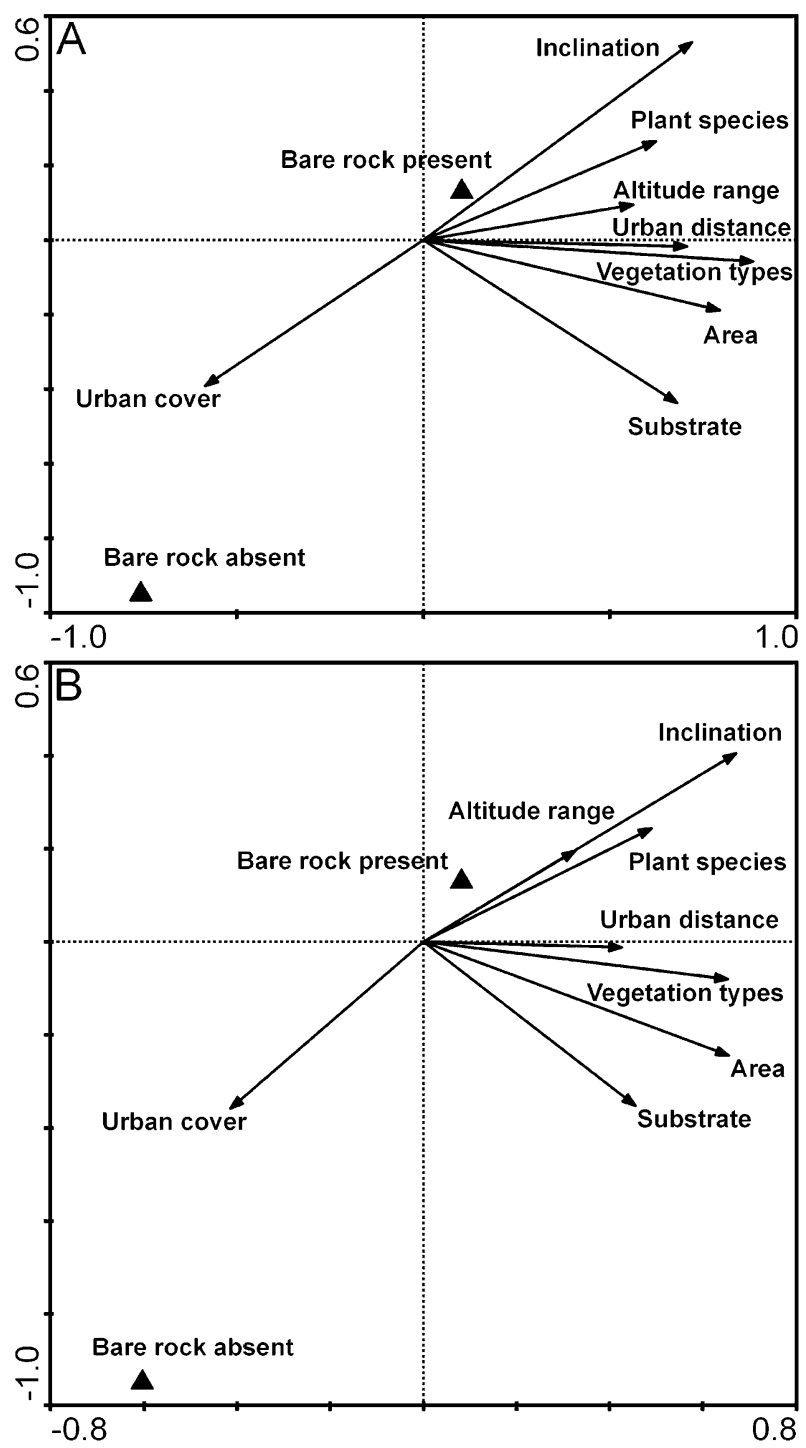

Fig. 3. Relative position of predictors (environmental variables) in RDA ordination of Prague reserves and parks according to butterfly species composition. A - all nominally significant predictors used as explanatory variables; B - previous model bud controlled for spatial position of the sites. For statistical parameters see Table 2.

\section{Reserve characteristics: urbanisation gradient}

In RDAs with single predictors, those exhibiting the strongest effects on the composition of the butterfly fauna were Vegetation types, Area and Urban distance, each explaining over $8 \%$ of the variation in species data. Further strong predictors were Inclination, Substrate, and Plant species (Fig. 2). Spatial terms fitted $5.8 \%$ of variation, and their inclusion expectably decreased the variation attributable to individual predictors. It also rendered Altitude range and Bare rock not significant, likely due to the location of all reserves with high values of Altitude range and containing Bare rock, i.e. deep rocky canyons, in the NW part of the city.

The RDA ordination with all nominally significant predictors accounted for $19.2 \%$ of the variation in species data (Table 2, Fig. 3A). All the predictors were intercor- 
TABLE 2. The RDA ordination with all nominally significant predictors. Minimal adequate models after forward selections with five predictors both not controlled (All) and controlled (All controlled for geography) for spatial positions of sites are presented.

\begin{tabular}{|c|c|c|c|c|c|c|c|c|c|c|}
\hline Predictors & $1^{\text {st }}$ axis & $2^{\text {nd }}$ axis & $3^{\text {rd }}$ axis & $4^{\text {th }}$ axis & $\begin{array}{c}\text { Sum } \\
\text { canon }\end{array}$ & Trace & $\begin{array}{l}F-1^{\text {st }} \\
\text { axis }\end{array}$ & $P$ & $\begin{array}{l}F \text {-all } \\
\text { axes }\end{array}$ & $P$ \\
\hline$\overline{\text { All }}$ & 0.134 & 0.016 & 0.013 & 0.010 & 1.00 & 0.192 & 29.34 & $*$ & 5.02 & $*$ \\
\hline Geography: lat + long + lat : long & 0.058 & 0.248 & 0.114 & 0.081 & 1.00 & 0.058 & 12.13 & $* *$ & & \\
\hline All controlled for geography & 0.088 & 0.017 & 0.013 & 0.010 & 0.942 & 0.152 & 19.56 & $* *$ & 3.86 & $* * *$ \\
\hline $\begin{array}{l}\sim \text { Vegetation types }+ \text { Inclination }+ \text { Substrate } \\
+ \text { Urban distance }+ \text { Area }\end{array}$ & 0.130 & 0.014 & 0.012 & 0.007 & 1.00 & 0.167 & 28.99 & $* * *$ & 7.93 & $* * *$ \\
\hline $\begin{array}{l}\sim \text { Vegetation types }+ \text { Inclination }+ \text { Substrate } \\
+ \text { Area }+ \text { Urban cover } \mid \text { lat }+ \text { long }+ \text { lat } \times \text { long }\end{array}$ & 0.087 & 0.013 & 0.009 & 0.007 & 0.942 & 0.137 & 19.60 & $* * *$ & 5.63 & $* * *$ \\
\hline
\end{tabular}

$1^{\text {st }}, 2^{\text {nd }}, 3^{\text {rd }}$ and $4^{\text {th }}$ - variation explained by individual ordination axes; Sum canon - the sum of canonical eigenvalues; $F$ and $P-$ Monte-Carlo permutation results $\left(P\right.$ values: $\left.*_{-}<0.05, * *-<0.01, * * *-<0.001\right)$.

related along the first ordination axis $(13.4 \%$ of explained variation). The axis formed a gradient from reserves that were large, far from the city centre, with many Plant species and Vegetation types, high Inclination (i.e., valleys or south facing) and alkaline bedrock, towards small sites close to city centre, surrounded by built-up land. The first axis thus stood for an increasing urbanisation effect. The second ordination axis accounted for just $1.6 \%$ of variation. It distinguished sites with high Inclination, hosting many Plant species and containing exposed bedrock, from all others sites.

Controlling for spatial positions of the sites decreased the explained variation (Table 2) but did not change the general pattern along the first ordination axis (Fig. 3B). Using forward selection of predictors returned models containing five variables each, both if controlled and not for spatial positions. The models differed in the predictors describing the degree of urbanisation: Urban distance entered the former, whereas Urban cover the latter (Table 2).

\section{Species responses to urbanisation gradient}

After applying the criteria for exclusion of rarely recorded species, we were left with 60 species (Table 3). Their responses to the first ordination axis (from Fig. 3B) corroborated the importance of the urbanisation gradient for practically all butterflies. 49 species $(80 \%)$ displayed a significant positive linear trend, or increasing probability of occurrence with decreasingly urban character of individual sites. No species showed a significantly negative trend, but eleven species did not display any trend at all.

Considering $A I C$ pointed to a more complex situation. This model-selection procedure revealed significant linear trends for 20 species. The responses of a further 29 species were more appropriately described by 2 nd-order polynomials, which were always concave, peaking above positive values of the first ordination axis, i.e. in relatively large, habitat-diverse reserves. We thus obtained three groups of species: those linearly increasing away from the city centre; those with polynomial responses apparently prospering somewhere along the 1 st ordination axis gradient; and those without any response, tolerating but not preferring urban environments (Fig. 4). Note that the non-responding species were abundant and/or frequent enough to meet the criteria applied for modelling the responses (Table 3, Appendix).

The three groups did not differ in the representation of endangered species $\left(\chi^{2}=0.39, \mathrm{df}=2, P=0.82\right)$, but differed in individual species' habitat associations $\left(\chi^{2}=\right.$ $11.67, \mathrm{df}=4, P=0.02)$. There was a surplus of mesophilous species among those with negatively linear response $(75 \%)$ and a surplus of xerophilous species among those
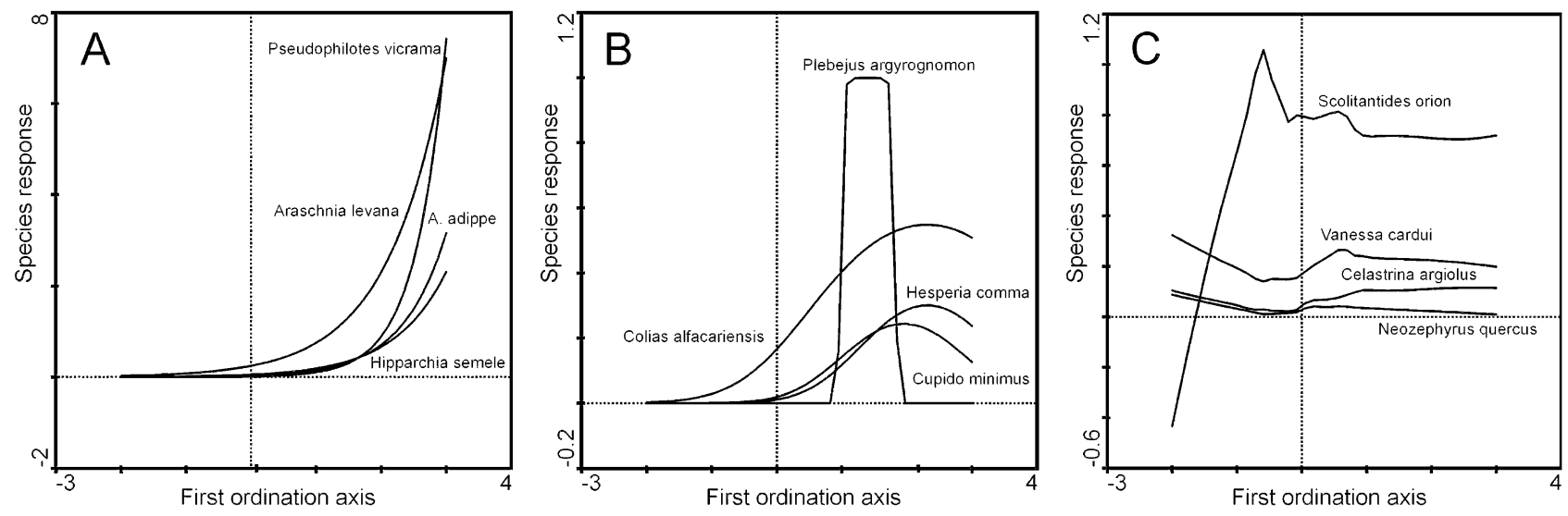

Fig. 4. Responses of selected butterfly species to 1st axis (RDA) containing all predictors and controlled for spatial position of sites (Fig. 3B). A and B - fitted by GLM method with a Poissons' distribution of errors and with log link function. Parsimony of the models was assessed by the Akaike information criterion; blocks show species better fitted by linear (A) and polynomial (B) functions. $\mathrm{C}$ - species without any significant statistical trends. The responses are visualized by a loess function. 
TABLE 3. Species responses to urbanisation gradient (1st ordination axis in Fig. 3A). Explained deviation (Dev), $P$ and $F$ values of significant models, values of Akaike information criterion of linear ( $A I C$ lin) and polynomial ( $A I C$ poly) functions are presented. Species observed in $<3$ sites, in abundances $<5$ specimens and with explained deviation $<0.05$ are omitted.

\begin{tabular}{|c|c|c|c|c|c|c|c|}
\hline & Dev & $F$ & $P$ & $A I C$ lin & $A I C$ poly & Habitat association & Red-list status \\
\hline NON-SIGNIFICANT & & & & & & & \\
\hline Aglais urticae & - & - & - & 278.9 & 280.0 & - & - \\
\hline Apatura ilia & - & - & - & 40.6 & 42.4 & MES & - \\
\hline Carcharodus alceae & - & - & - & 33.9 & 35.5 & XER & VU \\
\hline Celastrina argiolus & - & - & - & 183.7 & 186.1 & MES & - \\
\hline Neozephyrus quercus & - & - & - & 220.6 & 225.1 & MES & - \\
\hline Pararge aegeria & - & - & - & 226.3 & 229.3 & MES & - \\
\hline Pontia daplidice & - & - & - & 126.6 & 122.0 & - & - \\
\hline Satyrium accaciae & - & - & - & 383.3 & 382.9 & XER & VU \\
\hline Scolitantides orion & - & - & - & 547 & 550.2 & XER & VU \\
\hline Vanessa cardui & - & - & - & 359.4 & 362.5 & - & - \\
\hline $\begin{array}{l}\text { Zygaena carniolica } \\
\text { POLYNOMIAL TRENDS }\end{array}$ & - & - & - & 91.3 & 90.7 & XER & - \\
\hline Plebeius argyrognomon & 0.62 & 102.54 & $* * * *$ & 143.7 & 134.6 & XER & - \\
\hline Hesperia comma & 0.50 & 56.3 & $* * * *$ & 147.3 & 142.4 & XER & VU \\
\hline Cupido minimus & 0.47 & 62.11 & $* * * *$ & 160.8 & 151.7 & XER & - \\
\hline Limenitis camilla & 0.43 & 12.88 & $* * * *$ & 65.1 & 58.9 & MES & VU \\
\hline Colias alfacariensis & 0.38 & 57.68 & $* * * *$ & 264.4 & 250.9 & XER & - \\
\hline Coеnonympha pamphilus & 0.36 & 72.8 & ***** & 368.8 & 320.1 & - & - \\
\hline Spialia sertorius & 0.35 & 24.09 & $* * * *$ & 99.8 & 84.9 & XER & VU \\
\hline Polyommatus daphnis & 0.35 & 23.5 & $* * * *$ & 136.4 & 127.5 & XER & VU \\
\hline Argynnis aglaja & 0.34 & 17.86 & $* * * *$ & 41.2 & 32.0 & MES & - \\
\hline Boloria dia & 0.32 & 20.53 & $* * * *$ & 302.3 & 285.6 & XER & - \\
\hline Leptidea reali & 0.25 & 14.39 & ***** & 164.1 & 147.5 & MES & - \\
\hline Pyrgus malvae & 0.24 & 14.73 & $* * * *$ & 232.3 & 225.7 & MES & - \\
\hline Coenonympha arcania & 0.24 & 12.42 & $* * * *$ & 218.3 & 210.2 & XER & - \\
\hline Issoria lathonia & 0.23 & 22.11 & $* * * *$ & 229.8 & 221.6 & - & - \\
\hline Polyommatus icarus & 0.22 & 32.53 & $* * * *$ & 359.7 & 341.8 & - & - \\
\hline Polyommatus coridon & 0.21 & 22.55 & $* * * *$ & 532.8 & 526.5 & XER & - \\
\hline Aricia eumedon & 0.20 & 6.43 & $* *$ & 46.4 & 40.0 & MES & VU \\
\hline Aricia agestis & 0.20 & 15.72 & $* * * *$ & 182.9 & 181.9 & XER & - \\
\hline Thymelicus lineola & 0.17 & 17.33 & ***** & 454.0 & 438.7 & MES & - \\
\hline Thymelicus acteon & 0.17 & 5.08 & $* *$ & 95.9 & 87.9 & XER & $\mathrm{EN}$ \\
\hline Zygaena loti & 0.16 & 11.62 & $* * * *$ & 341.6 & 332.8 & XER & - \\
\hline Erynnis tages & 0.15 & 11.86 & $* * * *$ & 274.6 & 271.3 & XER & - \\
\hline Inachis io & 0.15 & 12.16 & $* * * *$ & 268.5 & 247.5 & - & - \\
\hline Maniola jurtina & 0.12 & 16.21 & $* * * *$ & 89.7 & 608.2 & - & - \\
\hline Melanargia galathea & 0.10 & 12.57 & $* * * *$ & 628.0 & 563.1 & MES & - \\
\hline Aphantopus hyperanthus & 0.10 & 7.48 & $* * *$ & 581.9 & 396.6 & MES & - \\
\hline Lycaena phlaeas & 0.06 & 4.83 & $* *$ & 216.7 & 219.1 & - & - \\
\hline Pieris napi & 0.05 & 7.09 & $* * *$ & 241.8 & 242.0 & - & - \\
\hline $\begin{array}{l}\text { Iphiclides podalirius } \\
\text { LINEAR TRENDS }\end{array}$ & 0.05 & 4.81 & $* *$ & 295.4 & 295.7 & XER & VU \\
\hline Pseudophilotes vicrama & 0.48 & 87.94 & $* * * *$ & 108.4 & 198.7 & XER & $\mathrm{EN}$ \\
\hline Araschnia levana & 0.46 & 88.85 & ***** & 198.6 & 351.2 & MES & - \\
\hline Argynnis adippe & 0.42 & 36.12 & $* * * *$ & 94 & 150.2 & MES & VU \\
\hline Hipparchia semele & 0.33 & 30.41 & $* * * *$ & 112 & 156.3 & XER & $\mathrm{CR}$ \\
\hline Erebia medusa & 0.32 & 24.25 & $* * * *$ & 175.9 & 239.1 & MES & - \\
\hline Pyrgus carthami & 0.31 & 38.71 & $* * * *$ & 232.3 & 320.1 & XER & VU \\
\hline Argynnis paphia & 0.29 & 54.23 & ***** & 318.7 & 433.3 & MES & - \\
\hline Polygonia c-album & 0.23 & 30.59 & $* * * *$ & 132.5 & 164.9 & MES & - \\
\hline Lycaena tityrus & 0.20 & 23.08 & $* * * *$ & 162.9 & 195.7 & MES & - \\
\hline Carterocephalus palaemon & 0.20 & 18.96 & $* * * *$ & 101 & 119.7 & MES & - \\
\hline Papilio machaon & 0.16 & 14.22 & $* * *$ & 112.6 & 127.7 & - & - \\
\hline Thymelicus sylvestris & 0.16 & 19.24 & $* * * *$ & 279.7 & 319.6 & MES & - \\
\hline Callophrys rubi & 0.16 & 6.83 & $* *$ & 63.6 & 68 & MES & - \\
\hline Zygaena filipendulae & 0.13 & 11.53 & $* * *$ & 161.6 & 176.2 & MES & - \\
\hline Gonepteryx rhamni & 0.11 & 12.31 & $* * *$ & 130.7 & 141.6 & MES & - \\
\hline Zygaena ephialtes & 0.10 & 5.53 & $*$ & 73.8 & 75.9 & XER & - \\
\hline Ochlodes venatus & 0.09 & 14.86 & $* * *$ & 339.0 & 340.1 & MES & - \\
\hline Satyrium spini & 0.09 & 6.26 & $*$ & 94.4 & 95.4 & MES & VU \\
\hline Lasiommata megera & 0.08 & 13.12 & $* * *$ & 260.7 & 261.5 & MES & - \\
\hline Pieris brassicae & 0.05 & 5.94 & * & 217.9 & 220.3 & MES & - \\
\hline
\end{tabular}


with polynomial response (48\%) to increasing urbanisation.

\section{DISCUSSION}

Butterfly assemblages inhabiting Prague reserves and parks are organised along a gradient from small sites with homogeneous conditions (i.e., low altitude range, low plant species and vegetation richness) to large and heterogeneous sites at city outskirts. The role of area, heterogeneity and plant and vegetation richness were similar to other studies of correlates of local butterfly diversity (Thomas et al., 2001; Yahner, 2001; Wenzel et al., 2006). In addition, sites with suitable conditions are mainly those found far from the city centre. This is attributable to historical expansion of the city, which proceeded eccentrically, completely transforming the central areas, and leaving more unaltered space in peripheral areas. We thus, as in other studies of urban butterflies, found that the composition of butterfly communities changes along a gradient of urbanisation (Blair \& Launer, 1997; Ruszczyk \& Araujo, 1992; but see also Collinge et al., 2003).

Contrary to Blair \& Launer (1997), who assessed the urbanisation effects on butterflies directly by walking transects from the periphery to the centre of urban Palo Alto, we recovered the urbanisation gradient indirectly, by ordination analysis of local assemblages. This approach is similar to other studies using indirect comparisons to assess urbanisation effects, such as comparison of species richness of urban and suburban grasslands (Ockinger et al., 2009); comparison of species richness of sites with different build-up cover (Hardy \& Dennis, 1999); or surveying gardens differing in size and location within a city (Di Mauro et al., 2007).

Although we cannot exclude some direct urbanisation effects, the most likely proximate factor appears to be diminishing habitat availability, as natural sites close to the city centre were smaller, more homogeneous in conditions, and surrounded by more built-up land. Everything else being equal, small insular sites support less species than large ones (Kadlec et al., 2008), heterogeneous sites host more species than homogeneous ones (Di Mauro et al., 2007), sites with more plant species will likely contain larval host plants of more butterfly species (Hawkins \& Porter, 2003). The overall greater diversity of butterfly resources (cf. Dennis et al., 2003) is reflected by a greater number of vegetation types, which is in fact a synthetic variable describing overall diversity of conditions (Jarosik et al., in press).

Similarly to Blair \& Launer (1997), we distinguished three groups of species according to their responses to urbanisation. Our results, however, differed from these authors in one important aspect. We detected groups of urban-avoiding (= increasing monotonously outwards from city centre) and suburban adaptable (= finding their optima at intermediate urbanisation levels) butterflies, but we did not detect any urban exploiters. Instead, we detected a group of butterflies not responding to urbanisation in any statistically recognisable way, and coin the term urban tolerant for this group.
In the Prague butterfly fauna, urban avoiders contained some extreme habitat specialists, such as sensitive shortgrasslands dwellers (Pseudophilotes vicrama, Pyrgus carthami), and a xerophilous species requiring truly large areas of appropriate biotopes, Hipparchia semele (cf. Benes et al., 2002; Kadlec et al., 2010). Prevailing, however, were mesophilous species, which inhabit woodlands or mesic grasslands in rural landscapes. Remnants of rural landscape are increasingly fragmented by urban sprawl, and practically nonexistent in city centres. Internal parts of Prague also produce high amounts of polluters such as nitrogen oxides (Pretel, 1996) likely affecting butterfly species richness (cf. Wallisdevries \& Van Swaay, 2006). For instance, the mesophilous species Erebia medusa depends on nitrogen-poor grasslands (Schmitt et al., 2000).

Suburban adaptable butterflies comprised a majority of all species. This group contained a high representation of xerophilous species, whereas mesophilous and ubiquitous species were underrepresented. Xerophilous members of this group apparently profit from the location of large xeric grassland reserves at the Prague periphery, but also from a dense network of industrial barrens, railway tracks or abandoned quarries scattered across Prague suburbia and collectively increasing both total area and connectivity of xeric vegetation (Jarosik et al., in press). Some ubiquitous (Coenonympha pamphilus, Thymelicus lineola) and highly mobile (Issoria lathonia, Inachis io) species also ended up in this group, perhaps owing to their ability to develop on weedy plants colonising urban barrens, or to utilise ornamental plants in parks and gardens (cf. Shapiro, 2002; Gaston et al., 2005). Many authors (Benes et al., 2003; Eyre et al., 2004; Saarinen et al., 2005; Tropek et al., 2010) showed that industrial and urban barrens may harbour insects depending on warm and dry microclimates. Wenzel et al. (2006) detected losses of many xerophilous species from isolated xeric reserves embedded within intensively farmed rural matrix, attributing this to isolation and spillover effects from the farmland.

Absence of positive responses to increasing urbanisation revealed that no butterfly species preferred urban environment: there were no "urban exploiters" sensu Blair \& Launer (1997). However, because our sample of sites did not contain such characteristic urban habitats as abandoned factory yards or railway tracks, we cannot entirely exclude that some species would be more abundant there than in the reserves or parks. Published examples of butterflies increasing in densities with increasing urbanisation are relatively rare. In California, such species exploit non-native ornamental or invasive host-plants (Shapiro \& Shapiro, 1973; Shapiro, 2002). European examples include the lycaenid Celastrina argiolus colonising planted woody legumes (e.g., Robinia pseudoacacia) in city parks (Hardy \& Dennis, 1999); the lycaenid Cacyreus marshalli invading Mediterranean cities and feeding on planted Pelargonium spp. (Eitschberger \& Stamer, 1990); or Lycaena coppers nectaring on invasive goldenrods (Solidago canadensis, S. gigantea), which 
form monodominant growths at urban barrens (cf. Root \& Cappucino, 1992).

Eleven species did not show any significant response at all, despite their high representation in our data. This group contained three highly mobile migrants developing on either dry (Pontia daplidice, Vanessa cardui) or mesic (Aglais urticae) ruderals. Three other species are usually regarded as xerophilous specialists, but can survive even in extremely small habitat patches. The lycaenid Scolitantides orion can persist at planted growths of its Sedum maximum host-plant at walls and rockeries; its persistence is also facilitated by a flexible regulation of annual numbers of generations (Traenkner \& Nuss, 2005). The skipper Carcharodus alceae, developing on mallows (Malva spp.), once a typical inhabitant of geese pastures (Benes et al., 2002), can occur on periodically mown warm ruderals (Sparmberg \& Boessneck, 2003) and in gardens (Straka, 2004), where it colonises planted mallows (Benyamini, 2005). The burnet Zygaena carniolica occurs even at small dry grasslands with rich nectar (Binzenhofer et al., 2005), persisting at dry ruderals or road margins.

The remaining five species not displaying any response develop either on shrubs and trees (Apatura ilia, Neozephyrus quercus, Celastrina argiolus, Satyrium accaciae), or on grasses amidst tree growths (Pararge aegeria). These common woodland or shrubland species occurred with equal probability in the periphery and in the city centre, implying that they view the canopy of urban parks, and of poorly managed reserves succumbing to succession (Barandovske skaly, Branicke skaly: cf. Kadlec et al., 2008), as suitable habitats. This contrasts with the observation that sites close to the city centre were practically devoid of otherwise widespread inhabitants of mesic grasslands developing on grasses (e.g., Maniola jurtina, Aphantopus hyperanthus, Ochlodes venatus) or on common meadow herbs (e.g., Lycaena tityrus, Leptidea reali). All of these common grassland species ended up in the suburban adaptable or urban avoiding groups. It is also notable that the five urban tolerant arboreal species rarely visit herbs for nectar, feeding either on aphid honeydew and sap (Corke, 1999) or on flowering shrubs. It follows that green areas near the centre of Prague provide suitable habitat for arboreal butterflies occurring in the canopy, but not for grassland butterflies occurring on the ground.

It is revealing to compare the absence of urban exploiters among Prague butterflies with another animal model group, birds. Fuchs et al. (2002) organised a gridbased survey of Prague birds, finding that the majority of birds occurring in the city centre, apart from a few originally rock-dwelling species such as rock doves and swifts, were species whose natural habitats would be woodlands. They colonise parks and gardens, but even green yards amongst buildings. In contrast, grassland and farmland birds tended to occur within the peripheral zone, similar to suburban-adaptable butterflies.

To summarise, although urbanisation affects the composition of local butterfly assemblages in Prague reserves and parks, the effect is not invariantly negative. About a third of the 85 species recorded (and half of the 60 species recorded with notable frequency) find their optima in Prague suburban belt. As this group contains a high proportion of xerophilous specialists, the Prague suburban belt represents important sanctuary for the endangered butterflies, and presumably other xerophilous insects (e.g., Padr, 1990; Strejcek, 2001). Some endangered species, however, occurred even among species indifferent to urbanisation, sustaining themselves at small habitat patches, or utilising artificial habitats such as walls and rockeries. An important observation was the presence of common woodland species, and the absence of common grassland species, in the Prague city centre. The common grassland species are most likely absent due to inappropriate management of lawns, consisting of too frequent or too tidy mowing. The impacts on both nectar availability and survival of developmental stages must be even stronger than in rural hay meadows, where frequent and uniform mowing demonstrably causes rapid crashes of butterfly populations (Konvicka et al., 2008; Dover et al., 2010). Small and cheap management modification, such as leaving aside small temporary fallows (Schmidt et al., 2009), would considerably improve the hospitability of urban green sites for butterflies. Much can also be achieved by small but well targeted measures, such as planting selected host plants in parks and gardens. Urban conservation will always be a compromise between the needs of animal species and the needs of humans, but small measures, if applied across large metropolitan areas, can substantially increase the supply of butterfly resources, increase the connectivity of urban reserves and help to avoid species losses.

ACKNOWLEDGEMENTS. We thank V. Jarosik and J. Benes for fruitful discussions, to J. Skala for companionship during field work and to two anonymous reviewers for useful comments. The study was supported by the Czech Science Foundation (P505/10/2167), Czech Ministry of Environment (VaV 620/2/03) and Education (MSM 6007665801, LC06073).

\section{REFERENCES}

Angold P.G., Sadler J.P., Hill M.O., Pullin A., Rushton S., Austin K., Small E., Wood B., Wadsworth R., Sanderson R. \& Thompson K. 2006: Biodiversity in urban habitat patches. Sci. Total Environ. 360: 196-204.

Benes J., Konvicka M., Dvorak J., Fric Z., Havelda Z., PavLicko A., Vrabec V. \& Weidenhoffer Z. (eds) 2002: Butterflies of the Czech Republic: Distribution and Conservation I, II. SOM, Praha, $857 \mathrm{pp}$.

Benes J., Kepka P. \& Konvicka M. 2003: Limestone quarries as refuges for European xerophilous butterflies. Conserv. Biol. 17: $1058-1069$.

BENYAMINI D. 2005: Euphorbiaceae - a new host-plant family for Carcharodus alceae Esper, 1780 (Lepidoptera: Hesperiidae) and a discussion on the use of Euphorbiaceae by butterfly larvae (Papilionoidea, Hesperioidea) in the world. Nota Lepidop. 28: 75-92.

Binzenhofer B., Schroder B., Strauss B., Biedermann R. \& Settele J. 2005: Habitat models and habitat connectivity analysis for butterflies and burnet moths - The example of 
Zygaena carniolica and Coenonympha arcania. Biol. Conserv. 126: $247-259$.

BLAIR R.B. 1999: Birds and butterflies along an urban gradient, surrogate taxa for assessing biodiversity? Ecol. Appl. 9: 164-170.

Blair R.B. \& LAUner A.E. 1997: Butterfly diversity and human land use, species assemblages along an urban gradient. Biol. Conserv. 80: 113-125.

Collier N., Mackay D.A., Benkendorff K., Austin A.D. \& CARTHEW S.M. 2006: Butterfly communities in South Australian urban reserves: Estimating abundance and diversity using the Pollard walk. Austral Ecol. 31: 282-290.

Collinge S.K., Prudic K.L. \& Oliver J.C. 2003: Effects of local habitat characteristics and landscape context on grassland butterfly diversity. Conserv. Biol. 17: 178-187.

Corke D. 1999: Are honeydew/sap-feeding butterflies (Lepidoptera: Rhopalocera) affected by particulate air-pollution? $J$. Insect Conserv. 3: 5-14.

DenNis R.L.H. \& HaRdY P.B. 2001: Loss rates of butterfly species with urban development. A test of atlas data and sampling artefacts at a fine scale. Biodivers. Conserv. 10: $1831-1837$

Dennis R.L.H., Shreeve T.G. \& VAn Dyck H. 2003: Towards a functional resource-based concept for habitat: a butterfly biology viewpoint. Oikos 102: 417-426.

Di Mauro D., Dietz T. \& Rockwood L. 2007: Determining the effect of urbanization on generalist butterfly species diversity in butterfly gardens. Urban Ecosyst. 10: 427-439.

Dover J.W., Rescia A., Fungarino S., Fairburn J., Carey P., Lunt P., Dennis R.L.H. \& Dover C.J. 2010: Can hay harvesting detrimentally affect adult butterfly abundance? $J$. Insect Conserv. 14: 413-418.

EitsChBerger U. \& STAMER P. 1990: Cacyreus marshalli Butler, 1898, eine neue Tagfalterart für die europäische Fauna? (Lepidoptera, Lycaenidae). Atalanta 21: 101-108.

Eyre M.D., LufF M.L. \& Woodward J.C. 2004: Beetles (Coleoptera) on brownfield sites in England: An important conservation resource? J. Insect Conserv. 7: 223-231.

Fuchs R., Skopek J., Formanek J. \& Exnerova A. 2002: Atlas hnizdniho rozšiřreni ptáků Prahy [Atlas of Breeding Birds in Prague]. Česká společnost ornitologická, Praha, 317 pp. [in Czech]

Gaston K.J., Smith R.M., Thompson K. \& Warren P.H. 2005: Urban domestic gardens (II): experimental tests of methods for increasing biodiversity. Biodiv. Conserv. 14: 395-413.

GuTIERREZ D. 2005: Effectiveness of existing reserves in the long-term protection of a regionally rare butterfly. Conserv. Biol. 19: 1586-1597.

Hardy P.B. \& Dennis R.L.H. 1999: The impact of urban development within a city region. Biodiv. Conserv. 8: 1261-1279.

Harrison C. \& DAviES G. 2002: Conserving biodiversity that matters: practitioners' perspectives on brownfield development and urban nature conservation in London. J. Environ. Manag. 65: 95-108.

Hawkins B.A. \& Porter E.E. 2003: Does herbivore diversity depend on plant diversity? The case of California butterflies. Am. Nat. 161: 40-49.

Hogsden K.L. \& Hutchinson T.C. 2004: Butterfly assemblages along a human disturbance gradient in Ontario, Canada. Can. J. Zool. 82: 739-748.

HötTINGER H. 2002: Checklist und Rote Liste der Tagschmetterlinge der Stadt Wien (Lepidoptera: Papilionoidea und Hesperioidea). Beitr. Entomofaunistik 3: 103-123.
Jarosik V., Konvicka M., Pysek P., Kadlec T. \& Benes J. 2011: Conservation in a city: plant and butterfly richness of urban reserves in Prague. Biol. Conserv. 144: 490-499.

Kadlec T., Benes J., Jarosik V. \& Konvicka M. 2008: Revisiting urban refuges: changes of butterfly and burnet fauna in Prague reserves over three decades. Landscape Urban Plan. 85: $1-11$.

Kadlec T., VRba P., Kepka P., Schnitt T. \& Konvicka M. 2010: Tracking the decline of the once-common butterfly: delayed oviposition, demography and population genetics in the hermit Chazara briseis. Anim. Conserv. 13: 172-183.

KitAhara M. \& FuJII K. 1994: Biodiversity and community structure of temperate butterfly species within a gradient of human disturbance - and analysis based on the concept of generalist vs. specialist strategies. Res. Popul. Ecol. 36: 187-199.

Knapp S., Kuhn I., Mosbrugger V. \& Klotz S. 2008: Do protected areas in urban and rural landscapes differ in species diversity? Biodiv. Conserv. 17: 1595-1612.

KoH L.P. \& SoDHI N.S. 2004: Importance of reserves, fragments, and parks for butterfly conservation in a tropical urban landscape. Ecol. Appl. 14: 1695-1708.

Konvicka M., Benes J., Cizek O., Kopecek F., Konvicka O. \& VitAZ L. 2008: How too much care kills species: grassland reserves, agrienvironmental schemes and extinction of Colias myrmidone (Lepidoptera: Pieridae) from its former stronghold. J. Insect Conserv. 12: 519-525.

Kühn I., BRANDL R. \& KLOtZ S. 2004: The flora of German cities is naturally species rich. Evol. Ecol. Res. 6: 749-764.

Lastuvka Z. (ed.) 1998: Checklist of Lepidoptera of Czech and Slovac Republics. Konvoj, Brno, 118 pp. [in Czech].

LEGENDRE P. 1993: Spatial autocorrelation - trouble or new paradigm? Ecology 74: 1659-1673.

Lundholm J.T. \& RichaRdSON P.J. 2010: Habitat analogues for reconciliation ecology in urban and industrial environments. J. Appl. Ecol. 47: 966-975.

Mattoni R., Longcore T., Zonneveld C. \& Novotny V. 2001: Analysis of transect counts to monitor population size in endangered insects: the case of the El Segundo blue butterfly, Euphilotes bernardino allyni. J. Insect Conserv. 5: 197-206.

MCINTYRE N.E. 2000: Ecology of urban arthropods: A review and a call to action. Ann. Entomol. Soc. Am. 93: 825-835.

Miller J.R. \& HobBs R.J. 2002: Conservation where people live and work. Conserv. Biol. 16: 330-337.

Nemec L. \& Lozex V. (eds) 1997: Protected Areas in the Czech Republic 2 Prague. Consult, Praha, 156 pp. [in Czech].

Ockinger E., Dannestam A. \& Smith H.G. 2009: The importance of fragmentation and habitat quality of urban grasslands for butterfly diversity. Landsc. Urban Plan. 93: 31-37.

PADR Z. 1990: Studie výskytu žahadlových blanokřidlých (Hymenoptera aculeata) na územi Prahy. [A Study about Occurrence of Aculeate Hymenoptera (Hymenoptera aculeate) at Boundary of Prague.] Natura Pragensis 7, Prague 179 pp.

Pretel J. 1996: Climatic Study for Needs of Prague City Plan. Utvar rozvoje mesta hl. m. Prahy, Prague [in Czech].

Root R.B. \& CAPpuCINo N. 1992: Patterns in population change and the organization of the insect community associated with goldenrod. Ecol. Monogr. 62: 393-420.

RuszczyK A. \& De Araujo A.M. 1992: Gradients in butterfly species diversity in an urban area in Brazil. J. Lepid. Soc. 46: 255-264.

SaARinen K., Valtonen A., Jantunen J. \& SAarnio S. 2005: Butterflies and diurnal moths along road verges: Does road type affect diversity and abundance? Biol. Conserv. 123: 403-412. 
Schmidt M.H., Rocker S., Hanafi J. \& Gigon A. 2009: Rotational fallows as overwintering habitat for grassland arthropods: the case of spiders in fen meadows. Biodiv. Conserv. 17: 3003-3012.

Schmitt T., Varga Z. \& Seitz A. 2000: Forests as dispersal barriers for Erebia medusa (Nymphalidae, Lepidoptera). Basic Appl. Ecol. 1: 53-59.

Shapiro A.M. 2002: The Californian urban butterfly fauna is dependent on alien plants. Divers. Distrib. 8: 31-40.

SHAPIRO A.M. \& SHAPIRO A.R. 1973: The ecological associations of the butterflies of Staten Island. J. Res. Lepid. 12: 65-128.

Shochat E., Warren P.S., Faeth S.H., McIntyre N.E. \& Hope D. 2006: From patterns to emerging processes in mechanistic urban ecology. Trends Ecol. Evol. 21: 186-191.

Snep R.P.H., Opdam P.F.M., BaVeco J.M., WallisDe VRies M.F., Timmermans W., KwaK R.G.M. \& Kuypers V. 2006: How peri-urban areas can strengthen animal population within cities: A modelling approach. Biol. Conserv. 127: $345-355$.

Sparmberg H. \& Boessneck U. 2003: Die Schutzgebiete der Landeshauptstadt Erfurt (Thueringen) Teil IX: Flora und Fauna des GLB "Feuchtwiese Schwansee". Veröff. NaturkdMus. Erfurt 22: 91-113.

Sprynar M. \& MareK M. 2001: Flora of the Prague Protected Areas. Proceedings of the Conference "Praga 2000 Natura Megalopolis”. EnviTypo, Prague, CD ROM. [in Czech].

StRAKA U. 2004: Stadgaerten als Lebensraum fuer Tagfalter: Beobachtungen in einem Garten in Stockerau (Niederoesterreich) in der Jahren 1999-2003. Beitr. Entomofaunistik 5: $67-78$.

Strejcek J. 2001: Katalog brouku (Coleoptera) Prahy. [Catalogue of Beetles (Coleoptera) of Prague.] Vol. 2. Hlavni mesto Praha, Praha, 142 pp.

Takami Y., Koshio C., Ishi M., Fuji H., Hidaka T. \& Shimizu I. 2004: Genetic diversity and structure of urban populations of Pieris butterflies assessed using amplified fragment length polymorphism. Mol. Ecol. 13: 245-258.

Ter Braak C.J.F. \& Smilauer P. 1998: CANOCO Reference Manual and User's Guide to Canoco for Windows. Software for Canonical Community Ordination (version 4). Centre for
Biometry Wageningen (Wageningen, NL) and Microcomputer Power (Ithaca NY, USA), $352 \mathrm{pp}$.

Thomas J.A., Bourn N.A.D., Clarke R.T., Stewart K.E., Simcox D.J., Pearman G.S., Curtis R. \& Goodger B. 2001: The quality and isolation of habitat patches both determine where butterflies persist in fragmented landscape. Proc. $R$. Soc. (B) 268: 1791-1796.

Titeux N., Dufrene M., Jacob J.P., Paquay M. \& Defourny P. 2004: Multivariate analysis of a fine-scale breeding bird atlas using a geographical information system and partial canonical correspondence analysis, environmental and spatial effects. $J$. Biogeography 31: 1841-1856.

Traenkner A. \& Nuss M. 2005: Risk spreading in the voltinism of Scolitantides orion orion (Pallas, 1771) (Lycaenidae). Nota Lepidop. 28: 55-64.

Tropek R., Kadlec T., Karesova P., Spitzer L., Kocarek P., Malenovsky I., Banar P., Tuf I.H., Hejda M. \& Konvicka M. 2010: Spontaneous succession in limestone quarries as an effective restoration tool for endangered arthropods and plants. J. Appl. Ecol. 47: 139-147.

Valtonen A., SaArinen K. \& Jantunen J. 2007: Intersection reservations as habitats for meadow butterflies and diurnal moths: Guidelines for planning and management. Landscape Urban Plan. 79: 201-209.

Vrabec V., Lastuvika Z., Benes J., Sumpich J., Konvicka M., Fric Z., Hrncir J., Matous J., Marek S., Kuras T., Hula V. \& Herman P. 2005: Lepidoptera. In Farkac J., Kral D. \& SкоRрік M. (eds): List of Threatened Species in the Czech Republic. Invertebrates. AOPK, Prague, pp. 172-237 [in Czech].

Wallisdevries M.F. \& VAN SwaAy C.A.M. 2006: Global warming and excess nitrogen may induce butterfly decline by microclimatic cooling. Glob. Change Biol. 12: 1620-1626.

Wenzel M., Schmitt T., Weitzel M. \& Seitz A. 2006: The severe decline of butterflies on western German calcareous grasslands during the last 30 years: a conservation problem. Biol. Conserv. 128: 542-552.

YAHNER R.H. 2001: Butterfly communities in residential landscapes of central Pennsylvania. Northeast. Nat. 8: 113-118.

Received March 25, 2010; revised and accepted November 29, 2010

APPENDIX. List of butterfly and burnet species recorded in 25 Prague reserves and parks in 2003-2004, with conservation status of individual species and maximal abundances recorded per site visit and (semiquantitative scale, see Material and methods).

\begin{tabular}{|c|c|c|c|c|c|c|c|c|c|c|c|c|c|c|c|c|c|c|c|c|c|c|c|c|c|c|}
\hline Species & 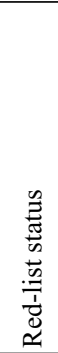 & 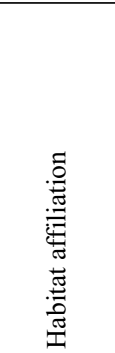 & 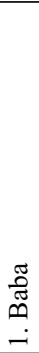 & 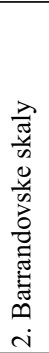 & 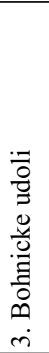 & 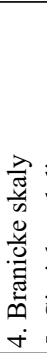 & 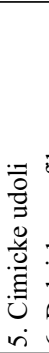 & 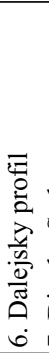 & 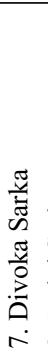 & 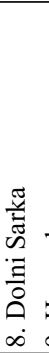 & 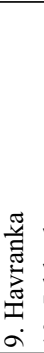 & $\begin{array}{l}\frac{\pi}{\tilde{a}} \\
\frac{0}{0} \\
\frac{0}{\tilde{I}} \\
\stackrel{0}{0}\end{array}$ & 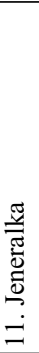 & 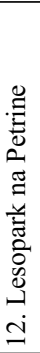 & 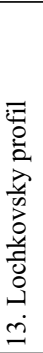 & 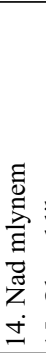 & 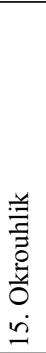 & 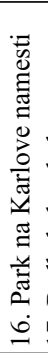 & 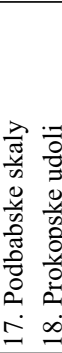 & 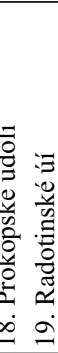 & 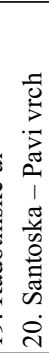 & 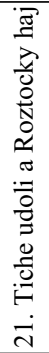 & 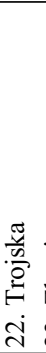 & . & 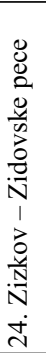 & 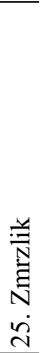 \\
\hline$\overline{\text { Adscita geryon (Hü, 1813) }}$ & NT & xer & - & - & - & - & - & - & - & - & - & - & - & - & - & - & - & - & - & -3 & - & - & - & - & - & $\overline{-}$ \\
\hline Adscita statices (Linnaeus, 1758) & - & xer, mez & - & - & - & - & - & - & - & - & - & - & - & - & 1 & - & - & - & - & $-\quad-$ & - & 2 & - & - & - & - \\
\hline Aglais urticae (Linnaeus, 1758) & - & - & 2 & 2 & 1 & 4 & 1 & 3 & 4 & 3 & 1 & 2 & 2 & 4 & 1 & - & - & 4 & 13 & 33 & 1 & 2 & 3 & - & 2 & 4 \\
\hline Anthocharis cardamines (Linnaeus, 1758) & - & mez & 4 & 4 & 4 & 3 & 4 & 3 & 4 & 3 & 3 & 4 & 3 & 2 & 2 & 3 & 1 & 1 & 25 & 56 & 3 & 4 & 4 & 3 & 2 & 5 \\
\hline Apatura ilia (Den. \& Schiff., 1775) & - & mez & - & 1 & - & - & - & 1 & - & - & - & - & - & - & - & 1 & - & - & - & -1 & - & - & - & 1 & - & - \\
\hline Apatura iris (Linnaeus, 1758) & - & mez & - & - & - & - & - & - & 1 & - & - & - & - & - & - & - & - & - & - & $-\quad-$ & - & - & - & - & - & - \\
\hline Aphantopus hyperantus (Linnaeus, 1758) & - & mez & 3 & 4 & - & 2 & 5 & 5 & 1 & 4 & 3 & - & 4 & - & 6 & 4 & - & - & 13 & 34 & 3 & 7 & - & 4 & - & 4 \\
\hline Aporia crataegi (Linnaeus, 1758) & NT & xer & - & - & - & - & - & - & 1 & - & - & - & - & - & - & - & - & - & -- & $-\quad-$ & - & - & - & - & - & - \\
\hline Araschnia levana (Linnaeus, 1758) & - & mez & - & - & 1 & - & 3 & 2 & 3 & 3 & 1 & 1 & 2 & 2 & - & 1 & 1 & 2 & & 46 & - & 5 & - & - & 1 & 5 \\
\hline Argynnis adippe (Den. \& Schiff., 1775) & VU & mez & - & - & - & - & - & - & - & 1 & - & - & - & - & 3 & - & - & - & -3 & 34 & - & - & - & - & - & 1 \\
\hline Argynnis aglaja (Linnaeus, 1758) & - & mez & - & - & - & - & - & 2 & - & - & - & - & - & - & 1 & - & - & - & & $1-$ & - & - & - & - & - & 1 \\
\hline Argynnis paphia (Linnaeus, 1758) & - & mez & 1 & 5 & 2 & 1 & - & 4 & 3 & 4 & 2 & - & - & & & 3 & - & - & -5 & 5 & - & 5 & & & & 4 \\
\hline
\end{tabular}


Aricia agestis (Den. \& Schiff., 1775)

Aricia eumedon (Esper, 1780)

Boloria dia (Linnaeus, 1767)

Brenthis ino (Rottemburg, 1775)

Callophyrus rubi (Linnaeus, 1758)

Carcharodus alceae (Esper, 1780)

Carterocephalus palaemon (Pallas, 1771)

Celastrina argiolus (Linnaeus, 1758)

Coenonympha arcania (Linnaeus, 1761)

Coenonympha glycerion (Borkhausen, 1788)

Coenonympha pamphilus (Linnaeus, 1758)

Colias alfacariensis Ribbe, 1905

Colias hyale (Linnaeus, 1758)

Cupido minimus (Fuessly, 1775)

Erebia medusa (Den. \& Schiff., 1775)

Erynnis tages (Linnaeus, 1758)

Gonepteryx rhamni (Linnaeus, 1758)

Hamearis lucina (Linnaeus, 1758)

Hesperia comma (Linnaeus, 1758)

Hipparchia semele (Linnaeus, 1758)

Inachis io (Linnaeus, 1758)

Iphiclides podalirius (Linnaeus, 1758)

Issoria lathonia (Linnaeus, 1758)

Jordanita globulariae (Hü, 1793)

Lasiommata megera (Linnaeus, 1767)

Leptidea reali Reissinger, 1989

Leptidea sinapis (Linnaeus, 1758)

Limenitis camilla (Linnaeus, 1764)

Lycaena phlaeas (Linnaeus, 1758)

Lycaena tityrus (Poda, 1761)

Maniola jurtina (Linnaeus, 1758)

Melanargia galathea (Linnaeus, 1758)

Melitaea athalia (Rottemburg, 1775)

Neozephyrus quercus (Linnaeus, 1758)

Ochlodes sylvanus (Esper, 1777)

Papilio machaon Linnaeus, 1758

Pararge aegeria (Linnaeus, 1758)

Pieris brassicae (Linnaeus, 1758)

Pieris napi (Linnaeus, 1758)

Pieris rapae (Linnaeus, 1758)

Plebeius argus (Linnaeus, 1758)

Plebejus argyrognomon (Bergsträ, 1779)

Polygonia c-album (Linnaeus, 1758)

Polyommatus amandus (Schneider, 1792)

Polyommatus coridon (Poda, 1761)

Polyommatus daphnis (Den. \& Schiff., 1775) VU

Polyommatus icarus (Rottemburg, 1775)

Polyommatus thersites (Cantener, 1834)

Pontia daplidice (Linnaeus, 1758)

Pseudophilotes vicrama (Moore, 1865)

Pyrgus carthami (Hü, 1813)

Pyrgus malvae (Linnaeus, 1758)

Rhagades pruni (Den. \& Schiff., 1775)

Satyrium acaciae (Fabricius, 1787)

Satyrium pruni (Linnaeus, 1758)

Satyrium spini (Den. \& Schiff., 1775)

Satyrium w-album (Knoch, 1782)

Scolitantides orion (Pallas, 1771)

Spialia sertorius (Hoffmannsegg, 1804)

Thecla betulae (Linnaeus, 1758)

Thymelicus acteon (Rottemburg, 1775)

Thymelicus lineola (Ochsenheimer, 1808)

Thymelicus sylvestris (Poda, 1761)

Vanessa atalanta (Linnaeus, 1758)

Vanessa cardui (Linnaeus, 1758)

Zygaena angelicae Ochsenheimer, 1808

Zygaena carniolica (Scopoli, 1763)

Zygaena ephialtes (Linnaeus, 1767)

Zygaena filipendulae (Linnaeus, 1758)

Zygaena laeta (Hü, 1790)

Zygaena loti (Den. \& Schiff., 1775)

Zygaena minos (Den. \& Schiff., 1775)

Zygaena viciae (Den. \& Schiff., 1775) $\begin{array}{lllllllllllllllllllllllllll}- & \text { xer } & 1 & - & - & 3 & 1 & 1 & 1 & - & 2 & - & 3 & 1 & 3 & - & 1 & 2 & 2 & - & 3 & 1 & - & 3\end{array}$

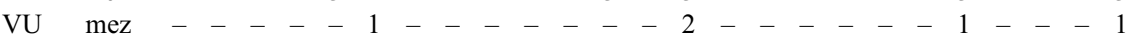

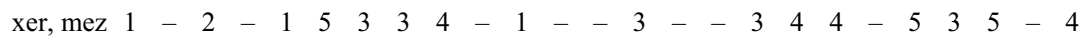

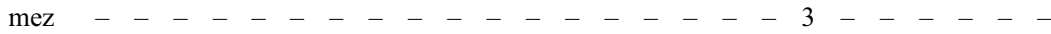

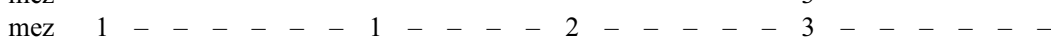

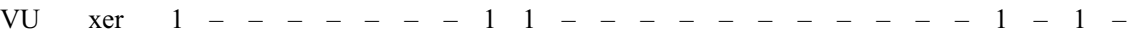

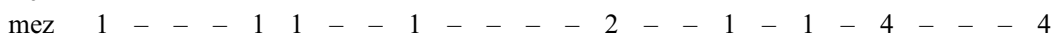

mez - $32-2$ - $22-1$ - $1--1-11-2-13-222$

xer, mez - - - $4-{ }_{-}-{ }_{-}-5-\ldots-\ldots-6$

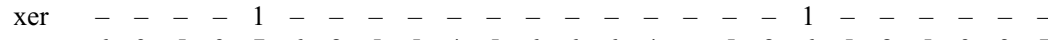

$\begin{array}{lllllllllllllllllllllllll}6 & 3 & 5 & 3 & 7 & 6 & 8 & 5 & 5 & 4 & 5 & 6 & 6 & 6 & 4 & - & 5 & 8 & 6 & 5 & 8 & 5 & 3 & 2 & 7\end{array}$

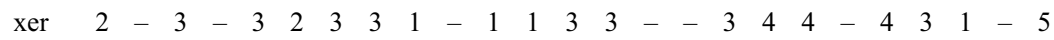

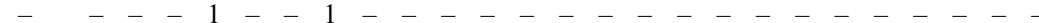

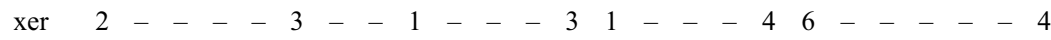

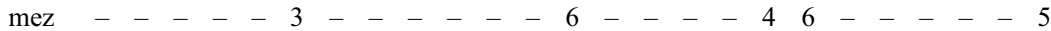

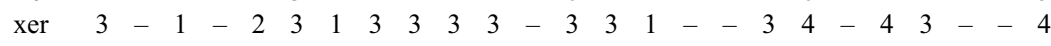

mez $-2 \begin{array}{lllllllllllllllllllllll} & 2 & 1 & - & 2 & 1 & - & 1 & - & - & - & 1 & 2 & - & 1 & 1 & 2 & 3 & 2 & 1 & - & 1 & -\end{array}$

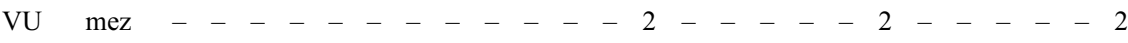

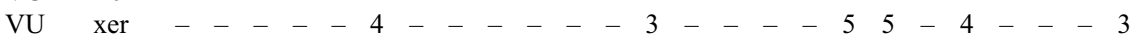

$\mathrm{CR}$ xer - - - - 1 - - - - - $3-\ldots$ - 33 - 3 - -

$\begin{array}{lllllllllllllllllllllllllllll}- & - & 1 & 3 & 1 & 3 & - & 2 & 3 & 2 & - & 2 & 1 & 3 & 1 & 1 & 1 & 4 & 1 & 3 & 5 & 1 & 4 & 1 & 1 & 3 & 5 \\ \text { VU } & x & 3 & 2 & 4 & 3 & 2 & 2 & 4 & 1 & 2 & 1 & 2 & 3 & 3 & 3 & 1 & 1 & 2 & 3 & 3 & 1 & 4 & 3 & 1 & 2 & 3\end{array}$

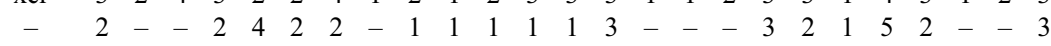

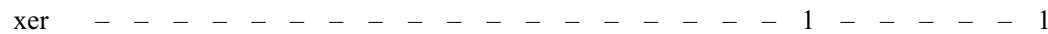

$\begin{array}{lllllllllllllllllllllllllll}\text { mez } & 3 & 1 & 2 & 3 & 1 & 3 & 3 & 1 & 2 & - & 1 & 1 & 3 & 2 & - & - & 1 & 4 & 2 & 3 & 3 & 2 & - & - & 1\end{array}$

mez - $1---3----2-23---2--2-\ldots$

VU xer, mez - - - $4-{ }_{-}-{ }_{-}-3-{ }_{-}-{ }_{-}-{ }_{-}-{ }_{-}-$

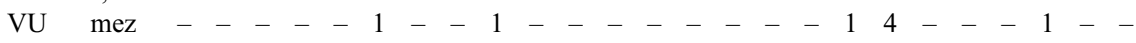

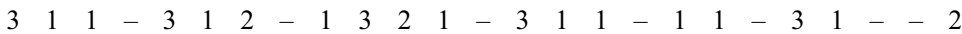

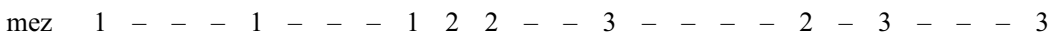
$\begin{array}{lllllllllllllllllllllllll}5 & 4 & 6 & 4 & 8 & 6 & 7 & 5 & 6 & 6 & 6 & 6 & 6 & 7 & 5 & - & 4 & 8 & 7 & 5 & 8 & 7 & 5 & 3 & 8\end{array}$

$\begin{array}{lllllllllllllllllllllllllllll}\text { mez } & 6 & 2 & 4 & 3 & 6 & 6 & 6 & 5 & 5 & 5 & 5 & 4 & 7 & 6 & 5 & - & 5 & 7 & 7 & 6 & 7 & 7 & 5 & - & 6\end{array}$

mez - - - - - - - - - - - - - - - $5-$ - - -

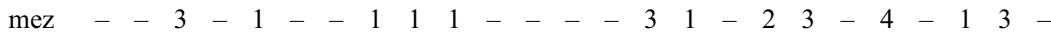

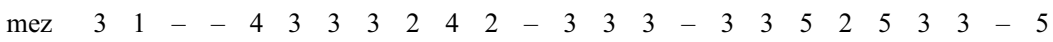
- -2 - 211 1 - - - - 31 - - - $13-1$ -

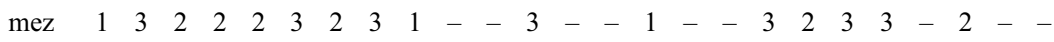

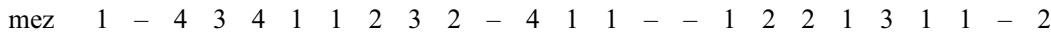

$\begin{array}{lllllllllllllllllllllllll}4 & 5 & 4 & 5 & 6 & 6 & 5 & 5 & 5 & 5 & 4 & 6 & 4 & 5 & 4 & 4 & 3 & 6 & 6 & 5 & 7 & 5 & 5 & 5 & 6\end{array}$

$\begin{array}{ccccccccccccccccccccccccc}5 & 6 & 6 & 5 & 6 & 5 & 6 & 5 & 5 & 5 & 5 & 6 & 5 & 5 & 5 & 5 & 4 & 6 & 6 & 6 & 6 & 6 & 5 & 6 & 5\end{array}$

xer - - - - - - - - - - - - - - - 3 - - - 1

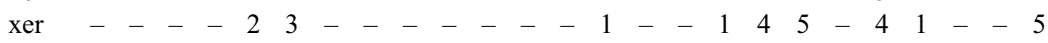

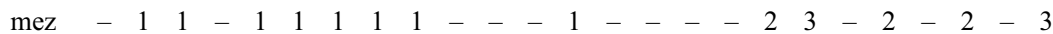

mez - - - - 2 - - - - - - - - - -1 - - - -

xer $5-4446-5334-86--378-42--8$

xer - - - - 3 - - - - - 42 - -33 - 3 - - - 5

$\begin{array}{lllllllllllllllllllllllll}3 & 1 & 2 & 3 & 4 & 5 & 4 & 3 & 4 & 4 & 5 & 6 & 4 & 5 & 3 & 1 & 3 & 6 & 4 & 4 & 5 & 6 & 1 & 1 & 5\end{array}$

VU xer $-\ldots-\ldots 1-\ldots-\ldots-\ldots-\ldots-\ldots$

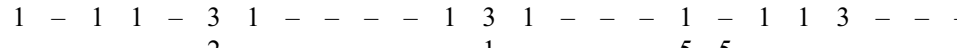

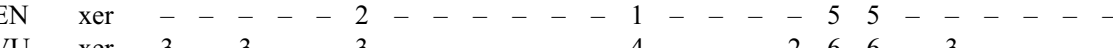

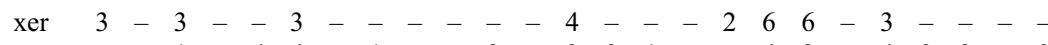

mez - - $1-44-1-{ }_{-}-2-231--43-432-3$

$\begin{array}{ccccccccccccccccccccccccccc}- & \text { xer } & - & - & - & - & - & - & - & - & - & - & - & - & - & - & - & - & - & - & 1 & - & 2 & - & - & - & - \\ \text { VU } & \text { xer } & 6 & 3 & 1 & 2 & - & 5 & 3 & 2 & 3 & 3 & 1 & - & 4 & 3 & - & - & 4 & 3 & 3 & 6 & 3 & 5 & - & - & 3\end{array}$

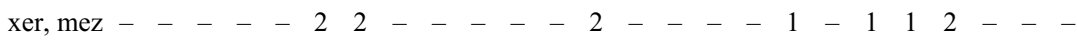

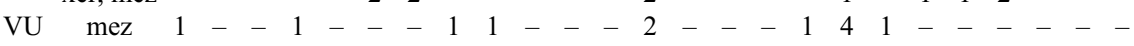

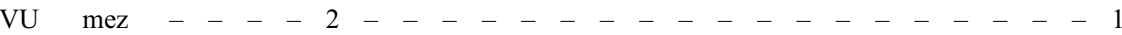

VU xer $\quad 6 \quad 6 \quad 6 \quad-\begin{array}{lllllllllllllllllllll} & 6 & 5 & 6 & 5 & 1 & 6 & - & - & 1 & 5 & - & - & 6 & 5 & 5 & 6 & 5 & 3 & 3 & -\end{array}$

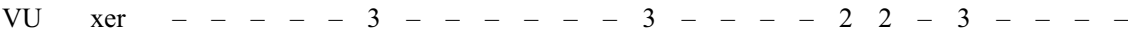

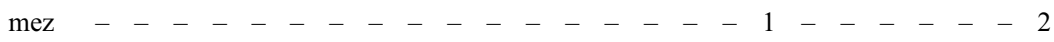

EN xer - - - - 2 - - - - - 4 - 4 - -12 - 2 - -

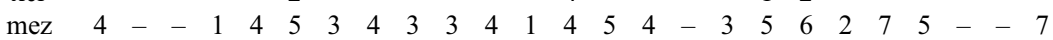

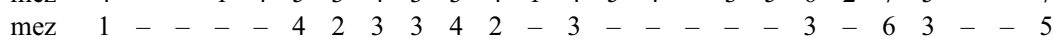

$\begin{array}{lllllllllllllllllllllllll}1 & 2 & 1 & 1 & 1 & 1 & 2 & 2 & 2 & 1 & - & 3 & - & 1 & - & - & 2 & 1 & 3 & 1 & 1 & - & 1 & - & 1\end{array}$

$\begin{array}{lllllllllllllllllllllllll}4 & 4 & 1 & 4 & 2 & 3 & 3 & 1 & 3 & 1 & 1 & 5 & 2 & 3 & 3 & 2 & 3 & 4 & 5 & 3 & 3 & 5 & 1 & 4 & 4\end{array}$

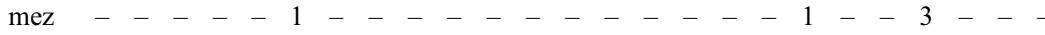

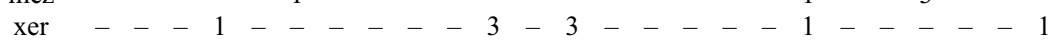

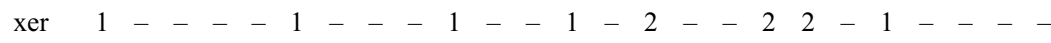

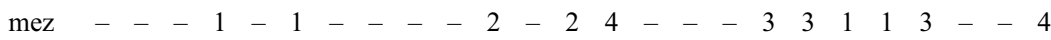

EN xer 6 - - - - - - - - - - - - - - - - - - - - -

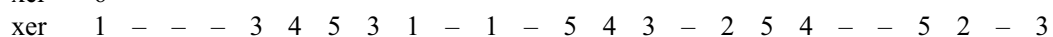

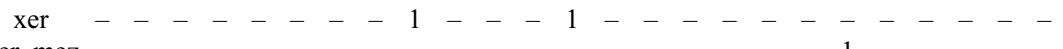

